predominantly an issue of safety for the elderly. In combination with more deaths now being attributed to carbon monoxide poisoning, new preventative strategies might be required.

\section{EVIDENCE-BASED FIRE SAFETY EDUCATION AND TRAINING MATERIAL FOR SOCIAL AND HEALTHCARE SERVICE PROVIDERS}

Tarja Ojala, Satu Pajala, Markus Grönfors, Nina Martikainen, Anne Lounamaa. National Institute for Health and Welfare, Finland

\subsection{6/injuryprev-2016-042156.415}

Background Fire safety in institutional care of vulnerable people in Finland is at a good level. However, in assisted living, residential and home care fatal fires still occur. Risk assessment, as well as knowledge of good procedures is therefore needed. Information of fire safety is included in vocational education of social and health care sector but for formal, non-formal and in-formal education material to improve care practices and identify the fire hazards at clients home is lacking.

Objective The aim of the project was to produce evidence-based educational material about fire safety for social and health care professionals. To produce this material, data gathered by National Institute for Health and Welfare, literature and good practices from social and health care and rescue services were utilised. The project took place 2012-2016 and was sponsored by Fire Protection Fund.

Results Fire safety education material for social and health care professionals, students and planners was first published in 2014. The web-based material includes information about background, legislation, fatal fire cases, principles of risk management and learning from accidents. In addition, there are statistic, special knowledge about fire sensitive fabrics, electrical equipment and chemicals and also good practices to improve fire safety. Additional compact educational package for craft teachers is available. The material can be used also in voluntary work and for example for people taking care of their relatives.

Conclusions Web-based material is freely available at https:// www.thl.fi/fi/tutkimus-ja-asiantuntijatyo/hankkeet-ja-ohjelmat/ step-hanke/stepin-koulutusaineisto. The material is available in Finnish and Swedish. English version is under consideration as there is urgent need of fire safety training also for increasing number of foreigners and immigrants in Finland.

\section{THE CAUSE OF BURN ACCIDENTS BY THE USE OF BIO- ETHANOL}

${ }^{1}$ Eva van Zoonen, ${ }^{1}$ Inti van Eck, ${ }^{2}$ Margriet van Baar. ${ }^{1}$ Dutch Burns Foundation, The Netherlands; ${ }^{2}$ Dutch Burn Repository Group, The Netherlands

\subsection{6/injuryprev-2016-042156.416}

Background Since 2010, commercially available bio-ethanol fuelled burners became increasingly popular in Europe. Unfortunately, the increase in bio-ethanol use resulted in an increase in the number of burn injury victims as a result of accidents with bio-ethanol. In 2010 there were 2 victims of accidents with bioethanol requiring admission in a Dutch burn centre, whereas this number rose to 29 victims in 2011. To assess what caused this sudden peak in accidents with bio-ethanol, a qualitative exploring research with a interpretative variant was performed.
Methods First, field research was conducted. Three experts on bio-ethanol (burners) were questioned in order to construct sensitising concepts as a background for framing the interviews. Second, non steering semi-structured interviews were conducted among 14 victims of a bio-ethanol burn accident. Complete transcripts of the recorded interviews were divided by thematic fragments and coded according to the sensitising concepts. All the identical coded fragments were combined.

Results Bio-ethanol was often misused, that is 8 of the 14 participants used the bio-ethanol as an accelerant for lighting up a fire or barbeque instead of using it for bio-ethanol fuelled burners.

All participants had poor knowledge of bio-ethanol use and most participants did not read the conditions of use. Vapour formation in half-full bio-ethanol bottles forms a major risk for an explosion, especially when there is a flame in close proximity when using bio-ethanol. Many of the bio-ethanol bottles were half-full when the accident happened and flames were still in place when using bio-ethanol.

Conclusions Bio-ethanol is cheap and easily obtainable, which creates an image of an innocent product. Instead, bio-ethanol is a product with a high risk of accidents when misused. Our outcomes showed that during accidents with bio-ethanol, there was a lack of knowledge, bio-ethanol was used for the wrong purpose and flames were still in place when using bio-ethanol.

\section{INCIDENCE AND EPIDEMIOLOGY OF BURNS TREATED IN THE WELSH CENTRE FOR BURNS}

${ }^{1}$ Angharad Walters, ${ }^{1}$ Ronan Lyons, ${ }^{1}$ Samantha Turner, ${ }^{1}$ Richard Fry, ${ }^{2}$ Tom Potokar. ${ }^{1}$ Farr Institute, Swansea University Medical School, Wales; ${ }^{2}$ Welsh Centre for Burns, Morriston Hospital, Wales

\subsection{6/injuryprev-2016-042156.417}

Background It is important to understand the epidemiology of burns in order to support the development and refinement of preventative measures. We used population based data from the Welsh Centre for Burns and Plastic Surgery (catchment area 2.3 million people) to study trends in the epidemiology of burns.

Methods Anonymised data from the Welsh Burns Centre have been included in the Secure Anonymised Information Linkage (SAIL) databank and linked to a population register. To describe the epidemiology of burns treated at the centre, data were restricted to acute injury assessments/admissions between 01/01/ 2003 and 31/12/2012 for patients who lived in Wales.

Results During the 10 years, there were 7160 acute injury admissions/assessments. There is an increasing trend in the rates over the decade, increasing from 26.6 per 100,000 population in 2003 to 31.9 in 2012 . Rates of burns in the home have increased from 13.2 per $100 \mathrm{~K}$ in 2003 to 20.8 in 2012 and more specifically, rates of burns in the kitchen have increased. During 2012, rates of treated burns were highest in males aged $0-4$. The $0-4$ age group suffer mainly from scalds followed by contact burns; contact burn rates have doubled over the ten years for this group of patients. Over the decade, rates were highest in the most deprived quintiles; however the rates are increasing in the least deprived and a substantial narrowing of the inequality can be seen over time. The distance travelled to Morriston hospital does not appear to be increasing over time and the severity of the burns have not changed over the decade; therefore the increase in the rate of treated burns does not appear to be due to an increasing rate of transfers of more serious burns from other hospitals in Wales. 